\title{
De "rebeldes, traidores, infieles, desleales y desobedientes" a vassalos d'El Rei: o princípio da devolução de índios no Rio da Prata colonial (1750 - 1763)
}

From "rebels, traitors, unfaithful , disloyal and disobedient" to the vassals d' El Rei: the principle of devolution of Indians in the colonial's Rio de la Plata(1750 - 1763)

Hevelly Ferreira Acruche*

\section{Resumo}

Neste artigo pretendemos trabalhar com os embates diplomáticos envolvendo Portugal e Espanha após a anulação do Tratado de Madri, assinado em 1750. Diante do fracasso da transmigração dos índios dos Sete Povos das Missões Orientais do Uruguai e a resistência indígena conhecida como Guerra Guaranítica (1754-1756), foi necessário retornar ao status anterior no conjunto das fronteiras americanas. A partir de então, uma nova disputa estava em jogo: o domínio e obediência dos povos indígenas que haviam passado pelo processo de transmigração e os conflitos em torno de sua devolução ao rei da Espanha, envolvendo elementos como escravidão e liberdade nas fronteiras do rio da Prata colonial.

Palavras-chave: fronteira - guarani - escravidão - liberdade - diplomacia.

\begin{abstract}
In this article we intend to work with the diplomatic clashes involving Portugal and Spain after the annulment of the Treaty of Madri, signed in 1750. In view of the failure of transmigration of the Indians of the Seven Peoples of the Eastern Missions of Uruguay and indigenous resistance called Guarani War (1754-1756), it was necessary to

\footnotetext{
* Professora de História pela Secretaria de Estado e Educação do Rio de Janeiro (SEEDUC). Doutoranda pela Universidade Federal Fluminense (Uff). Bolsista pela Coordenação de Aperfeiçoamento de Pessoal de Nível Superior (Capes).
} 
return to the previous status in the group of American borders. Since then, a rematch was at stake: the domain and obedience of indigenous people who had passed through the transmigration process and the conflict over its return to the King of Spain, involving elements such as slavery and freedom at the Rio de la Plata's borders.

Keywords: border - Guarani - slavery - freedom - diplomacy.

Recibido: 14 de diciembre de 2015

Evaluado: 26 de diciembre de 2015 
"Vossa fica a Colônia, e ficam nossos

Sete povos, que os Bárbaros habitam

Naquela oriental vasta campina

Que o fértil Uraguai discorre e banha.

Quem podia esperar que uns índios rudes,

Sem disciplina, sem valor, sem armas,

Se atravessassem no caminho aos nossos,

E que lhes disputassem o terreno!"

Basílio da Gama. O Uraguai, Canto primeiro. (1769)

Num bando publicado por ordem de D. José de Andonaegui, datado de 30 de junho de 1753, negros e mulatos livres eram convocados para se dirigirem a Praça pública de Buenos Aires, portando as armas que tivessem para servir ao governo de Sua Majestade, o rei da Espanha. Este pleito se dava pela necessidade de homens rumo às Missões, destacadamente para combater os índios tapes. Aos que não comparecessem, o castigo era "de Doscientos Azotes y cuatro años de destierro á el Presidio y Plaza de San Phelipe de Montevideu a trabajar en las obras de S.M. a ración y sin sueldo" ${ }^{\text {. }}$

O contexto que marca este período é o da chamada Guerra Guaranítica (17541756), ou seja, o conflito entre portugueses, espanhóis e indígenas em torno da permuta dos territórios da Colônia do Sacramento pelos territórios da margem oriental do rio Uruguai, os chamados Sete Povos das Missões previsto pelo Tratado de Madri, assinado em 1750 para dar fim às contendas entre lusos e espanhóis. Os esforços empreendidos para a demarcação das fronteiras entre os reinos ibéricos na América, somada a insatisfação dos povos indígenas que viviam naquelas paragens como vassalos do rei da Espanha, acarretou numa guerra onde como consequência final tivemos a anulação do Tratado de Madri, em 1761.

Negros, livres ou escravos, participaram deste processo, seja nas comissões de demarcação, seja como participes do processo de retirada dos aldeados do território missioneiro. Por isso, pode se considerar que a fronteira que estava em discussão naquele momento era um espaço de múltiplos contatos, relações e permeada de singularidades que a faziam ser, no conjunto geopolítico colonial, um espaço cada vez mais importante. Nesse sentido, é possível compreender a participação de negros como força militar para conter os povos indígenas rebelados, bem como algumas das múltiplas interações sociais existentes nesse território. Tropas negras em contato com os descendentes de nativos pressupunha, de um lado, uma série de interações étnico-sociais que poderiam surgir, como também ressalta algumas das estratégias utilizadas no decorrer do conflito. Naquele momento, todos deveriam servir a causa de contenção dos povos missioneiros que reivindicavam o direito a uma terra que consideravam deles, a qual o rei espanhol não poderia se desfazer.

Assim, o objetivo deste artigo é analisar os conflitos em torno do fenômeno da transmigração dos índios oriundos das Missões e as consequências desta transmigração nos anos seguintes. Nossa intenção é mostrar como os agentes diplomáticos dos Impérios ibéricos no Prata lidaram com a situação vigente, sobretudo com a resistência indígena ao Tratado. Sabe se que sua anulação, em 1761, fora fruto de problemas no

${ }^{1}$ AGN. Sala IX. 8-1-2. Bandos. Libro 2o . Fls. 22-23. 
continente europeu e das dificuldades materiais e financeiras das expedições no processo de demarcação; mas o peso do conflito com os índios na América levou a busca de novas alternativas e uma nova orientação para o relacionamento entre as metrópoles e suas respectivas colônias. Esta alternativa, representada pelo Tratado de El Pardo, significava um retorno ao status anterior a 1750. No entanto, novas questões surgiram no decorrer dos anos 1760; onde a fluidez dos territórios no extremo sul da América ibérica permitiu a mobilidade de pessoas e a necessidade de um controle maior sobre as gentes diante das escolhas individuais ou coletivas; ressaltando uma das fragilidades dos Estados reformistas português e espanhol em suas colônias.

\section{O contexto do Reformismo ibérico: guerra, resistência e mobilidade.}

“A razão porque fazemos menos apreço das Missões do Solimões, não se nos dando de perder alguma coisa por aquela parte, contanto que adquiramos para o Sul, é porque da banda do Sul com a comunicação marítima do Rio da Prata têm os espanhóis maior poder, e nos convém equilibrá-lo, alargandonos para o interior e formando naquela parte uma província poderosa. E com esse fim se vão mandando continuamente para ela grande número de casais das ilhas, dos quais, feito que seja o ajuste, poderão passar bastantes a ocupar o sítio das Aldeias do Urugua i, se ficarem sem índios. E dentro em breves anos poderá toda aquela província achar-se povoada e em tal estado de forças, que nada receie dos espanhóis”.

Alexandre de Gusmão, 14/09/1749.

Quando, em 13 de janeiro de 1750, os reis de Portugal e Espanha assinaram o Tratado de Madri, um dos pontos das negociações foi a troca de territórios considerados equivalentes. Dentro dos princípios norteadores do uti possidetis e de fronteiras naturais, inaugurados pelo diplomata português Alexandre de Gusmão, lusos e hispânicos empreenderam um primeiro esforço de divisão territorial já que o avanço bandeirante permitiu uma expansão dos territórios portugueses para além da linha de Tordesilhas $^{2}$. Os territórios a serem permutados eram a Colônia do Sacramento, palco de disputas entre portugueses e espanhóis desde sua fundação, em 1680, e os Sete Povos das Missões, situado na margem oriental do rio Uruguai.

Pelos termos do Tratado de 1750, os Sete Povos passavam do domínio espanhol para o português, e a Colônia lusitana, passava para os espanhóis ${ }^{3}$. Os missioneiros e os indígenas viventes nas Missões fronteiriças localizadas tanto nos Povos orientais do Uruguai quanto nas margens dos rios Pequiri, Guaporé e Amazonas deveriam levar seus pertences móveis e semoventes e se "aldear em outras terras de Espanha ${ }^{4}$ ". Portanto, os planos de Alexandre de Gusmão, descritos em parte na epígrafe acima, lançam luz às

\footnotetext{
${ }^{2}$ Monteiro, 1994.

${ }^{3}$ Filho, 2000.

4 Tratado de Limites das Conquistas entre os muito altos, e Poderosos Senhores D. João V, Rei de Portugal e D. Fernando VI, Rei da Espanha. Madri, 13 de janeiro de 1750 (Artigo XVI. Cortesão, 2006: 370).
} 
estratégias de apropriação do território das Missões do Uruguai que poderiam, dentro de curto prazo, prejudicar os interesses espanhóis na região platina.

O processo demarcatório foi, por si só, complicado. A elaboração do Mapa das Cortes, modelo para a demarcação territorial do conjunto da América ibérica, serviu a propósitos portugueses em torno da soberania territorial na medida em que uma série de longitudes foram erroneamente calculadas; o que dava aos espanhóis a falsa impressão de ocuparem um território maior. Roberto Simonsen afirmou que os portugueses esperavam, com a configuração errônea do Mapa, uma melhor aceitação do princípio de uti possidetis por parte dos espanhóis. Entretanto, pesquisas mais recentes têm pontuado que a presença de erros no Mapa das Cortes serviu a propósitos geopolíticos portugueses coadunados a uma série de modificações a fim de reordenar a administração territorial da América lusa ${ }^{5}$. E, para tanto, a ocupação do território era imprescindível, conforme Alexandre de Gusmão pontuava em 1749, "se ficarem sem índios".

As comissões mistas, enviadas por lusos e espanhóis para o trabalho de demarcação nas fronteiras norte e sul da América era composta por diversos profissionais, tais como os "cosmógrafos, responsáveis pelos trabalhos de astronomia e cartografia; alferes, para o mando dos soldados; capelães, para os remédios espirituais; e cirurgiões, para as enfermidades do corpo. A eles se somavam soldados índios, escravos - negros para o serviço, pilotos e demais trabalhadores”6. A atuação de escravos era fundamental aos serviços gerais das partidas demarcatórias, o que evidenciava também as dificuldades em torno do recrutamento de pessoas para tal missão. Ademais, muitas vezes as comissões hispano-portuguesas contaram com os conhecimentos obtidos por indígenas para fazer o reconhecimento de regiões pouco documentadas - em especial a fronteira amazônica - e dos marcos a serem estabelecidos a partir de elementos da natureza, a imprecisão dos mapas e bulas antigas e o pouco conhecimento obtido sobre a astronomia em períodos anteriores dificultaram o bom andamento das expedições ${ }^{7}$.

Contudo, esse processo não se deu de forma simples. Uma parte da povoação indígena missioneira foi contra à efetivação do Tratado. $\mathrm{O}$ mal-estar gerado diante do que eles interpretavam como uma traição do monarca espanhol ao ceder as terras indígenas, as quais os índios aldeados defenderam continuamente do avanço português, simbolizava uma reação a indefinição das fronteiras e também a antecipação de novas lógicas e disputas em torno da propriedade da terra ${ }^{8}$. Porém, tal aspecto se uniu a um conjunto de estratégias empregadas tanto por espanhóis quanto por lusitanos a fim de atrair a população missioneira.

Desta feita, a interação entre estes personagens fronteiriços poderia beneficiar os interesses de um lado ou de outro, sobretudo ao levarmos em conta que desde pelo menos os idos de 1740 era um consenso para as autoridades dos Impérios ibéricos a necessidade de ocupação dos diversos espaços fronteiriços do Novo Mundo numa direção pautada na captação de povoadores ${ }^{9}$. Temos, nesse sentido, a deflagração da

\footnotetext{
${ }^{5}$ Kantor, 2014: 464.

${ }^{6}$ Costa, 2009: 192-193.

${ }^{7}$ Barcelos, 2010: 1-15.

${ }^{8}$ Quarleri, 2009: 197.

${ }^{9}$ Landers, 1999: 37. Ao abordar o papel desempenhado por Gomes Freire de Andrada na demarcação das fronteiras, Mônica da Silva Ribeiro também aborda a questão da ocupação territorial levando em
} 
Guerra Guaranítica entre 1754 e 1756, ocorrida no decorrer das ações das partidas de demarcação e da consequente transmigração dos guaranis, no qual os interesses de índios, jesuítas, portugueses e espanhóis estavam em jogo ${ }^{10}$.

Além disso, a transmigração dos povos guarani na margem oriental do Uruguai produziu divisões inevitáveis no seio destes povos. Algumas reduções, como São Borja, agiram de forma passiva e obediente enquanto outras abriram resistência às tropas lusas e hispânicas como, por exemplo, São Miguel e São Nicolau ${ }^{11}$. Motins e outros atos de resistência foram organizados no território missioneiro. Alguns caciques queimaram carros e juntaram os cavalos e bois, assim como usaram armas de fogo atreladas ao tradicional arco e flecha ${ }^{12}$. Nesse sentido, a Guerra Guaranítica foi travada entre guerreiros de ambos os lados; o que garantia uma resistência a transmigração pautada numa traição do monarca espanhol e, por conseguinte, a defesa da manutenção da comunidade indígena dentro de uma dada territorialidade. Imbuída de um sentido de lutas seculares contra os avanços portugueses e de proteção aos súditos do rei, os missioneiros se colocavam tendo direitos próprios sobre a terra. A missão era, no interior do processo de colonização na América espanhola, uma instituição da fronteira consolidada pelas ações tanto da Igreja quanto dos nativos que viviam nesses espaços enquanto um instrumento defensivo contra possíveis invasões e que ajudava, por fim, a disseminação da fé cristã entre os gentios ${ }^{13}$.

Com as notícias da resistência indígena, José de Andonaegui estava preocupado em demonstrar sua lealdade ao rei católico dentro do conflito e, ao mesmo tempo, posicionar-se num contexto onde o que estava em jogo era a boa relação entre Portugal e Espanha. Por isso, ele emitiu numa carta a Matías Strobel, Superior das Missões, a seguinte sentença quanto aos nativos rebelados:

"Confirmo el delito de lesa magestadis y los declaro en nombre del Rey Nuestro Señor y mío por rebeldes, traidores, infieles, desleales y desobedientes vassalos: procederé contra ellos con todo el rigor de las armas, haré cuantos daños pueda en sus vidas y haciendas hasta exterminarlos y acabarlos enteramente para que no quede memoria de gente tan perversa que no merece el patrocinio de ningún monarca de la tierra"14.

Portanto, para Andonaegui, os índios se transformaram em vassalos infiéis e desleais ao rei católico, não merecendo sua graça e atenção no que dizia respeito às terras reclamadas. Eles deveriam ser destinados ao "rigor das armas" e ter danos consideráveis em suas vidas e propriedades diante de tamanha desobediência. A

consideração a ideia de captar gentes para garantir ocupação das fronteiras estabelecidas (Ribeiro, 2014: 105).

10 Segundo Elisa Garcia, os exércitos de Portugal e Espanha deveriam tentar entrar nos Povos separadamente. Com o fracasso desta tentativa, os dois se uniram numa única frente, em 1756, derrotando as forças dos índios na Batalha de Caiboaté.

${ }^{11}$ Quarleri, 2009: 169.

12 Ibidem: 175-176. Cabe ressaltar que o uso de armas de fogo era comum nas Missões sob o argumento de proteger as populações nativas do avanço de "mamelucos portugueses" e de ameaças de escravização.

${ }^{13}$ Bolton, 1991: 45-60.

${ }^{14}$ Archivo Nacional Histórico. CARTA del Gobernador de Buenos Aires José de Andonaegui a Matías Strobel, superior de las Misiones. Buenos Aires, 12/05/1753. Santiago de Chile, Jesuitas de Argentina, vol. 202, peça 12, f. 25v. 
garantia da entrega do território dos Sete Povos a Portugal foi confiada a Lope Luis Altamirano, comissário especial da Companhia de Jesus, que deveria "zelar pela honra da Companhia" e cumprir o "real serviço". Altamirano, ao observar que boa parte dos jesuítas do Paraguai eram contrários ao Tratado, interpretou que os nativos eram comandados pelos jesuítas, sendo aqueles incapazes de produzir uma estratégia de organização própria. Tal visão do conflito permeou o imaginário dos monarcas europeus e contribuiu para um desgaste cada vez maior da Companhia nas Américas ${ }^{15}$.

Além do desgaste que a Companhia sofreu no decorrer do conflito, outros elementos contribuíram para uma acirrada disputa pela não transmigração. Um deles era a persistência da concepção, difundida em boa parte pelos lusitanos, de que os padres da Companhia escravizavam os índios e os maltratavam no espaço missioneiro. Estas informações no decorrer da segunda metade do Setecentos, sejam reais ou ilusórias, tinham um sentido histórico bastante definido e estava presente na memória daqueles guaranis cujas famílias se aldearam, muitas vezes, fugindo de ameaças dos encomenderos e dos bandeirantes paulistas.

Assim, tanto o significado atrelado ao território quanto o papel da escravização são pedra de toque a compreensão das ações e expectativas tanto dos indígenas quanto das autoridades representantes das coroas ibéricas de ambos os lados da fronteira. As crescentes insatisfações quanto as formas de trabalho aplicadas nas Missões, que tinha pouco retorno em termos financeiros, se tornaram argumento suficiente pra caracterizar as ações dos padres como uma forma de escravização ${ }^{16}$.

Por outro lado, o que se depreende da documentação e dos relatos produzidos posteriormente aos acontecimentos é que as ações dos indígenas no conflito tinham sido fruto de uma tendência liderada pelos jesuítas a serviço do rei Católico, e não uma ação própria de um povo ameaçado de sair de terras onde viveu e se estabeleceu como grupo. Nesse caso, a presença de lideranças religiosas no continente americano consistia numa ameaça vital aos interesses e planos de reforma que as monarquias ibéricas almejavam naquele momento, culminando na expulsão dos inacianos da América ${ }^{17}$ e a dinamização da administração temporal das regiões missioneiras.

As ações dos sujeitos no decorrer do conflito demonstram tanto suas possibilidades quanto suas expectativas no cotidiano de uma fronteira em constante processo de mudança. Um caso emblemático nesse sentido é o de Sepé Tiaraju, um dos líderes da resistência guarani, que convivia com portugueses e espanhóis no reduto fronteiriço da aldeia de São Miguel. Tal convivência era importante pois era o que o ajudava a obter informações de ambos os lados. Numa dessas investidas, Tiarajú teve 53 de seus soldados reféns e transformados em prisioneiros das tropas portuguesas no forte de São Miguel. Isso representou um sinal de fragilidade da resistência guarani. Porém, a intenção dos portugueses era reaver cavalos que foram tomados pelos guaranis e realizar uma troca de prisioneiros por animais. Doze soldados portugueses foram selecionados

\footnotetext{
${ }^{15}$ De acordo com Lia Quarleri, a situação da Companhia era tão caótica ao ponto de se difundir a ideia de que o espaço missioneiro fora vendido aos portugueses pela própria instituição. Tal situação levou a fuga de Altamirano das Missões rumo a Buenos Aires em 1753 (Quarleri. 2009: 182).

${ }^{16}$ García, 2013: 85.

${ }^{17}$ Em 1759, o Marquês de Pombal decretou a expulsão dos jesuítas dos domínios portugueses. O mesmo fenômeno ocorreu sob o governo de Carlos III na Espanha, em 1767. No caso espanhol, Lia Quarleri afirma que a atuação dos jesuítas na Guerra Guaranítica foi fundamental para a perda de importância da Igreja católica em todo o Império espanhol (Quarleri, 2009).
} 
para acompanhar Sepé Tiarajú até a estância de São Luis a fim de reaver os ditos cavalos. Contudo, os animais foram passados a outra margem do rio e já se encontravam em poder de outras pessoas; o que serviu como justificativa para levar os reféns a vila do Rio Grande; onde Gomes Freire de Andrada os esperava.

Na viagem, permeada de motins dos prisioneiros contra a tripulação lusitana, sobreviveram 12 a 13 índios que passaram a viver uns meses de "cativeiro". Era recorrente no imaginário dos nativos que os portugueses iriam escravizá-los, o que justificava a tentativa de dar fim a viagem antes da chegada ao Rio Grande. Gomes Freire enfatizou através de discursos e diálogos com os próprios nativos - fugidos ou não dos povos - a existência de um bom tratamento dos portugueses em oposição constante ao escravismo perpetrado pelos padres ${ }^{18}$. Ademais, permitiu que eles retornassem aos povos para contar sua experiência no seio dos portugueses, o que nos permite observar uma postura dúbia do futuro conde de Bobadela. Por um lado, os portugueses poderiam ser aliados potenciais dos guarani; mas, por outro, poderiam se transformar em inimigos declarados dos nativos. Portanto, o uso da dissimulação para governar estava presente nas ações de Gomes Freire de modo a buscar, através do conhecimento das redes sociais e de poder na região, uma espécie de neutralidade ${ }^{19}$.

As reformas bourbônicas e as reformas pombalinas, concebidas sob inspiração das primeiras, previam uma série de mudanças para as colônias americanas. Dentre estas mudanças, aquelas diretamente associadas aos povos indígenas estão arroladas na lei de liberdades (1755), a qual foi incorporada ao chamado Diretório dos índios, produzido pelo Marquês de Pombal em 1757. O objetivo de ambos os documentos era produzir dispositivos sobre a integração dos índios à sociedade lusitana a fim de extinguir as diferenças entre índios e brancos. A ideia central era assimilar os indígenas ao conjunto de súditos da América portuguesa através do incentivo a casamentos mistos e do ensino da língua portuguesa em substituição ao nheengatu, dialeto original dos povos guarani. Inicialmente aplicado no norte, esta legislação foi gradualmente estendida a toda a América portuguesa ${ }^{20}$. Estas mudanças dialogavam com a lógica de bom tratamento a ser dispensada aos índios, pensada por Gomes Freire no contexto das guerras pelos Sete povos orientais, visando assimilá-los para transformá-los em súditos de Sua Majestade Fidelíssima a fim de consolidar as relações sociais que foram estabelecidas no decorrer do conflito. Nesse ínterim, o conhecimento da esfera local e das gentes que viviam naquele espaço era fundamental

Uma das proibições do Diretório era o hábito corrente de chamar os índios de "negros da terra" ou de "negros"21. Isso serviu para demarcar o lugar desses indivíduos nas hierarquias sociais da América lusitana e, ao mesmo tempo, produzir diferenciações entre indígenas e africanos, sejam estes escravizados ou livres. Além disso, deve se levar em conta também que a aplicação do Diretório variou conforme a região e os grupos indígenas que viviam nesses espaços. Neste sentido, a demografia indígena era essencial para o sucesso ou fracasso das políticas indigenistas ${ }^{22}$.

\footnotetext{
${ }^{18}$ Garcia, 2007.

19 Ribeiro, 2014: 103.

${ }^{20}$ Garcia, 2009: 74 - 75.

${ }^{21}$ Biblioteca Nacional. Divisão de Manuscritos. Morgado de Mateus. Resumo dos capítulos do Diretório dos Índios. “§10 - Que nunca se lhe chamem negros, caboclos.” MS - 553 - 25.

22 Sampaio, 2001.
} 
Os trabalhos especializados sobre o Diretório dos índios e as consequências de sua aplicação na América portuguesa estiveram focados, inicialmente, na fronteira norte. Uma das questões colocadas na bibliografia especializada ressalta a importância de se promover um ordenamento no acesso a mão de obra indígena a fim de manter o trabalho destes indivíduos. No decorrer dos séculos XVII e XVIII, uma série de medidas foram aplicadas, ora para garantir a liberdade dos índios, ora para prover os colonos de mão de obra através dos descimentos privados. Nestes descimentos, em parte havia uma lógica de organização da mão de obra e, em parte, uma série de complicações pelas quais a capacidade de negociação dos índios poderia se mostrar eficiente; garantindo os seus interesses ${ }^{23}$.

A partir da segunda metade do Setecentos, a transição da fase de gentio para a de vassalo da Coroa portuguesa vinha acompanhada da incorporação de novos grupos em aldeamentos. Esses descimentos, comandados pelos Principais nomeados pela administração metropolitana, permitiu envios de mão de obra dos sertões do Grão Pará para outros territórios do Vale Amazônico, o que incidia diretamente na vida cotidiana dessas populações, sua mobilidade e a construção de fronteiras entre o mundo selvagem e o mundo civilizado ${ }^{24}$. Tais intervenções levaram também a um aumento do envio de mão de obra africana para o local através da criação de companhias de comércio privadas $^{25}$, uma das bases ao fomento da economia gestadas por Pombal.

Os impactos destas reformas na esfera local, entretanto, podem explicar as articulações políticas e sociais dessas populações, o que lança outras perspectivas ao entendimento dos projetos metropolitanos as Conquistas americanas ${ }^{26}$. Estas não impediram a manutenção de contatos em ambos os lados da fronteira, e nem conseguiram dirimir as diferenciações entre os súditos ${ }^{27}$, com destaque aos indígenas em relação à sociedade colonial. Embora o espírito da lei exprimisse uma noção de igualdade, na prática social esta não se fazia presente nestes termos. Nesse caso, escravos, índios, proprietários, comerciantes, entre outros, conviviam e se articulavam nesse espaço, de modo a dotá-lo de especificidades que dificultaram a implantação tanto do projeto pombalino à colônia portuguesa quanto do projeto bourbônico às colônias espanholas $^{28}$; e que essas nuanças poderiam também ter reflexos nas relações diplomáticas entre Portugal e Espanha.

Tomando as áreas fronteiriças, em especial o Rio Grande, é possível sublinhar que a necessidade de aplicação das medidas reformistas era urgente. Em 2 de maio de 1771, o vice-rei do Brasil, Marquês do Lavradio, enviou ao Governador do Rio Grande uma missiva cobrando a aplicação das medidas pombalinas no Rio Grande

"porque vendo [os índios] que os domínios de Portugal passam as da sua mesma nação sem a sujeição ao cativeiro, que eles experimentam é (...) natural que se

\footnotetext{
${ }^{23}$ Bombardi, 2011 y Chamboleyron, 2011: 601-623.

${ }^{24}$ Sampaio, 2011: 11.

${ }^{25}$ Idem: 84.

${ }^{26}$ Garcia, 2011: 55-57.

${ }^{27}$ Almeida, 2001. Especificamente sobre os impactos do Diretório na fronteira sul, ver o trabalho Garcia, 2007: 74-85.

${ }^{28}$ Idem.
} 
passem todos para os domínios de d'el rei meu senhor fidelíssimo, vindo desta sorte a diminuírem as forças dos espanhóis e aumentarmos as nossas”29.

Ainda no texto da carta, Lavradio afirmou não estar "consentindo que os maltratem por forma alguma" a fim de atrair os povos indígenas aos domínios lusitanos, "desenganando-se do horror que os espanhóis tinham feito conceber do nome português". A política do "bom tratamento" lusitano em oposição aos espanhóis, que assemelhavam os indígenas aos escravos, fazia parte de um dos esforços dos portugueses para garantir a ocupação do Rio Grande. Por outro lado, tal política abria novos horizontes às autoridades fronteiriças na medida em que uma muralha de gente poderia garantir a posse, bem como a legitimidade do domínio, de territórios em nome de uma das duas Coroas.

Portanto, assim como os problemas de ordem técnica e inerentes às comissões, os efeitos da resistência indígena missioneira - embora produzida em um grau de improvisação onde a numerosa tropa e o impacto geográfico pouco conhecido pelos europeus poderiam vir a fazer a diferença -, levaram ao colapso das tentativas de demarcação dentro dos meios propostos em 1750. Além disso, a morte de Fernando VI e a ascensão de Carlos III ao trono espanhol permitiram uma mudança de rumos das relações internacionais da Espanha. Por isso, houve certa aceitação para proceder a revogação do Tratado de Madri pelo Tratado de El Pardo, assinado em 12 de fevereiro de $1761^{30}$. Assim, a situação fronteiriça na América ibérica retornou ao status de antes de 1750, em que Espanha continuava com o domínio sob o território das Missões e Portugal, da Colônia do Sacramento.

Nesse contexto, os planos de reforma das Coroas portuguesa e espanhola estavam em curso com a coroação da dinastia dos Bourbons na Espanha e a morte de D. João V em Portugal e a coroação do novo rei, D. José I, que tinha em seu primeiro ministro - o marquês de Pombal -, uma liderança capaz de promover mudanças no relacionamento entre a Coroa e suas colônias. Contudo, as necessidades e expectativas dos indígenas nas áreas fronteiriças estavam circunscritas a elementos imediatos do cotidiano, tais como a busca por melhorias nas condições de vida e de trabalho, inclusive a manutenção de costumes tribais, argumentos estes que levaram a tentativas de obtenção da liberdade fora do território das Missões. Assim, as alianças empreendidas entre indígenas e portugueses foram sacramentaras a partir de oposições entre um governo e outro, colocando em evidência a dicotomia escravidão e liberdade; o que por sua vez teve como ápice a expulsão dos inacianos da América.

\section{O Tratado de El Pardo: flutuações na fronteira.}

Em 1761, Portugal e Espanha assinaram o Tratado de El Pardo. Seu texto era muito simples: tratava da anulação das diretrizes estabelecidas pelo Tratado de Madri ${ }^{31}$.

\footnotetext{
${ }^{29}$ ANRJ. Carta do Vice Rei, Marquês do Lavradio, ao Governador do Rio Grande, José Marcelino de Figueiredo. Rio de Janeiro, 02/03/1771. Fundo Marquês do Lavradio, microfilme 024-97, RD 54.104.

${ }^{30}$ Através deste Acordo, o Tratado de Limites da Ásia e América, firmado 11 anos antes, foi cancelado em todos os seus pontos. Foi decretada a destruição de todas as habitações, casas e fortalezas construídas por ambas as partes em virtude desse Tratado.

31 Seu primeiro artigo estabelecia que “(...) Com todos os outros tratados ou convenções que em consequência dele foram celebrando para ajustar as instruções dos respectivos 3 comissários que até agora se empregaram nas demarcações dos referidos limites, e todo o acordado em virtude delas, se dão
} 
Seu caráter revogatório é analisado a partir de, pelo menos, duas interpretações complementares: a primeira delas analisa o contexto político das monarquias peninsulares, na qual seus governantes discordavam das decisões tomadas no acordo de 1750, o que por sua vez alimentava a desarmonia no continente americano. A outra argumentação considera os efeitos do Tratado de Madrid e a demarcação, sobretudo na América Meridional, levando em conta a resistência indígena contrária a cessão dos Sete Povos das Missões ${ }^{32}$ como fator para minar as estratégias traçadas por Alexandre de Gusmão.

O consenso das monarquias ibéricas a renunciar ao Tratado de 1750 deve ser retratado a luz da necessidade de ambas em, através da manutenção territorial, manterem seu poder, soberania e confiança. Num contexto onde a aquisição de territórios poderia acarretar na atração de novos súditos, era importante a concretização do domínio dos territórios coloniais novas formas de tratamento e de administração da questão fronteiriça.

Assim, o contexto da Guerra dos Sete Anos (1756 - 1763) é, para fins deste trabalho, fundamental a compreensão dos problemas ocorridos no continente americano, no qual as alianças estabelecidas entre França e Espanha - de um lado - e Inglaterra e Portugal, de outro, se destacou nos impactos sofridos nas Conquistas. Ao mesmo tempo, a Guerra dos Sete Anos foi o clímax da inimizade ibérica após um breve período de paz. De acordo com Jeremy Adelman:

"A luta real, como de costume, aconteceu nas colônias, onde dois impérios conviviam. Na fronteira do Rio da Prata, forças espanholas e seus aliados indígenas usaram a ocasião para levar os brasileiros a margem leste [do rio] $]^{33, \text {. }}$

Embora a aliança entre ingleses e portugueses estivesse vigente, Portugal manteve, sob a administração pombalina, a neutralidade, mas acabou por entrar no conflito às pressas, dadas as ameaças de invasão espanhola ${ }^{34}$. As condições de Portugal no Velho Mundo eram precárias, dada a ascensão da dinastia Bourbon na Espanha e a criação do terceiro Pacto de Família entre França e Espanha ${ }^{35}$. Pode se afirmar que os efeitos da Guerra dos Sete Anos foram sentidos de formas distintas no conjunto dos territórios do Império espanhol. Desta forma, entendemos que na região platina aconteceu o recrudescimento de inimizades e problemas já existentes, oriundos em grande parte da transmigração dos indígenas no contexto de execução do Tratado de Madri.

Em relação aos territórios, a Colônia do Sacramento voltava a ser de domínio português enquanto os Sete Povos das Missões, ao mando espanhol. No entanto, o que notamos é que, em relação aos povos das Missões Orientais do Uruguai, este retorno ao

e permanecem em força do presente por cancelados, caçados e anulados como se nunca houvessem existido nem houvessem sido executados (...)”.

${ }^{32}$ Essas duas interpretações são analisadas no livro de Synesio Sampaio Goes Filho, que afirma a opinião dos pesquisadores em relações internacionais sobre as falhas de El Pardo, por um lado, e as vitórias obtidas através da continuidade das ideias de Gusmão, sobretudo o uti possidetis, à formação do território brasileiro (Filho, 2000: 192-193).

33 Adelman, 2006: 19.

34 Novais, 2011: 48.

${ }^{35}$ Maxwell, 1997: 111-112. 
status anterior a 1750 não foi tão fácil assim. Trazer novamente os índios aos seus povos de origem não pareceu ser uma tarefa simples. Isso se justifica pois, a partir daquele momento, os indígenas que porventura estivessem em paragens de domínio português passavam a ser considerados fugitivos da Coroa espanhola. E, enquanto fugitivos, deveriam ser devolvidos a seus respectivos governos como uma forma de estabelecer um controle das pessoas que por esta fronteira indeterminada e porosa transitassem. E, em termos geográficos, o rio Uruguai passava a ser uma fronteira natural entre os domínios de portugueses e espanhóis.

O governo de Jose de Andonaegui não suportou a derrota dos espanhóis na Guerra Guaranítica e, em seu lugar, o General D. Pedro de Cevallos foi nomeado Governador de Buenos Aires. Em uma orientação enviada por D. Ricardo Wall a Cevallos, responsável pelo ordenamento do processo de demarcação das fronteiras no Rio da Prata, se ponderava que cabia ao mesmo o cuidado e zelo de realizar, em nome de Sua Majestade Católica:

"la reposicion de las cosas al ser y estado que tenian antes del tratado, y con advertirle que en esto se incluye tambien la restitucion, que los Portugueses deben hacer de los Indios de los Pueblos que sedujeron y retienen en su Ejercito, ó Pais" ${ }^{36}$.

Esta orientação dizia exatamente a nova função de Cevallos diante das notícias de anulação do Tratado. A execução do processo de devolução dos índios dos Povos que foram seduzidos e retidos pelos portugueses em territórios sob seu domínio. Tal prática não era incomum na América. Nos primeiros tempos coloniais, existem alguns registros de pedidos de devolução de índios fugitivos atendidos pela Coroa espanhola ${ }^{37}$. Em meados do século XVIII, percebemos que, a partir do fracasso do Tratado de Madri, as possibilidades de pedir pela devolução de índios foram redimensionadas a fim de reaver aqueles súditos perdidos e “seduzidos” pelos portugueses. Tal mudança ia de encontro ao estabelecido no Artigo XVI do referido Tratado, onde estava claro que "os índios de uma e outra parte terão a mesma liberdade para se irem ou ficarem”.

Além de cuidar da devolução dos índios transmigrados para as terras portuguesas, cabia a Cevallos uma outra missão no Prata: iniciar um processo contra os jesuítas a fim de averiguar sua participação na Guerra Guaranítica. Nas palavras de Lía Quarleri, "el proceso promovido por Cevallos tuvo como resultado, por el arte de testimonios, un relato de los sucesos y una imagen de los jesuitas contraria a la que crecia en el mundo" ${ }^{38}$. Nesse contexto, Portugal já havia expulsado os inacianos de todos os seus domínios e a intenção do Governador de Buenos Aires era fazer frente ao Marquês de Valdelírios e ao bispo da diocese, Manuel Antonio de la Torre, ambos contrários aos missioneiros. Portanto, passamos a entender o uso de um discurso anti jesuítico no Novo Mundo quando este vem associado ao contexto da Guerra Guaranítica e a possível liderança dos jesuítas nesse processo.

\footnotetext{
${ }^{36}$ AGN. Sala IX. 28-2-21. CARTA de D. Ricardo Wall a D. Pedro de Cevallos. Bom Retiro, 19/09/1760. Archivo General de Indias. Sessão V. Audiência de Buenos Aires. f. 2v.

${ }^{37}$ AGI. Devolución de indios a Francisco Velásquez (14/11/1509). Indiferente, 418, L. 2, fls. 93 R - 94 R. Orden sobre la devolución de indios al Ldo Maldonado (24/10/1510). Indiferente, 418, L. 2, fls. 146 - 146 $\mathrm{R}$.

${ }^{38}$ Quarleri, 2009: 320 - 321.
} 
Ademais, acreditamos que a divulgação de uma série de boatos envolvendo a prática de escravização de índios pelos Padres da Companhia de Jesus contribuiu para a sua expulsão da América hispânica, em 1767. No decorrer do processo demarcatório e da consequente Guerra Guaranítica, uma série de cartas foram trocadas entre as autoridades luso e hispânicas discutindo, entre outros assuntos, a transmigração dos indígenas e o tratamento dado a eles pelos portugueses como parte de uma estratégia de bom tratamento em nome do rei de Portugal ${ }^{39}$.

Num relato do ano de 1754, um fugitivo de nome Cristóbal Izaguirre, natural do povo da Cruz, afirmou que muitos índios dos povos de uma banda ou outra do rio Uruguai estavam coligados em defesa de suas terras e, para isto, se mantinham com "índios infieles, charruas, bojanes, para no dejar entrar portugueses" ${ }^{40}$. As interações no espaço fronteiriço permitiram a construção de alianças de grupos unidos muitas vezes pelo parentesco, mas afastados pela ingerência das Missões e pela doutrina católica; o que também servia de justificativa para o não retorno destes aldeados às Missões após o fim do conflito.

Em 1757, numa carta enviada a D. Ricardo Wall por Gomes Freire de Andrada, foi noticiado um aviso de que um grupo de famílias de índios haviam passado das estâncias de Gomes Freire. De acordo com suas listas, o total era de setecentas e sessenta e uma pessoas nas paragens do Rio Pardo. O que levava esses índios a saírem do território missioneiro? De acordo com a mesma carta, isso se justificava por dois motivos: primeiro, a uma série de ameaças dos Paulistas, os quais diziam que "los españoles los han de matar” e que os Povos que viviam as margens do rio Paraná e na margem ocidental do Uruguai estavam em pior estado e desassistidos de suas necessidades ${ }^{41}$.

Em continuidade, no documento fora registrado que os indígenas eram tratados com toda a benignidade e assistidos no que era necessário a cada um desde a transmigração. No entanto, mesmo experimentando um doce e amoroso tratamento, "hallarán realmente verificados los efectos del temor que les han infundido" ${ }^{42}$. Ou seja, o temor de ameaças de morte era real por parte dos indígenas; o que poderia tornar as ações dos paulistas verossímeis e servia como justificativa para evitar o retorno destes índios ao monarca espanhol.

"Las medidas que se han tomado para atraer aquellos Indios, parece imposible que dejen de producir el buen efecto que se desea de desengañarlos para que vuelvan; ni seran bastante para estorbarlo las impressiones de los Paulistas, si estos no insisten en ellas, del modo que no podrian hacerlo estando presente $D$. Gomes Freire, sino fuesen mandados, y aún que esto no será fácil probarlo, algo que podrá indagar por los Indios que venan, aunque sean pocos, para manifestar la sospecha de um procedimiento tal"43.

\footnotetext{
${ }^{39}$ Ver, entre outros o trabalho de Elisa Garcia. As diversas formas de ser índio. Políticas indígenas e políticas indigenistas no extremo sul da América Portuguesa. Rio de Janeiro: Arquivo Nacional, 2007.

${ }^{40}$ Quarleri, 2009: 297-298.

${ }^{41}$ AGN. Sala IX. 28-2-21. Carta de Gomes Freire de Andrada ao D. Ricardo Wall. São Borja, 07/12/1757. Archivo General de Indias. Sessão V. Audiência de Buenos Aires. f. 2.

${ }^{42}$ Idem.

${ }^{43}$ Idem.
} 
Na semana seguinte, Gomes Freire relatava a Pedro Cevallos a deserção de muitos índios pelo rio Jacuí em retirada, “como loucos”, rumo aos Ervais ou a Santo Antônio Velho. Estes índios vinham dos Povos de São Lourenço, São Nicolau e Santo Ângelo e haviam chegado a um forte português seis dias antes desta deserção. Suspeitava-se da influência de um peão, ou um negro, ou mesmo um língua para a ocorrência esta atitude, pois os mesmos alegavam que eram tratados de forma diferente dos outros índios na outra margem do Uruguai, onde sofriam ultrajes tais como forçar as mulheres a cortar o cabelo, o que era considerado por eles um castigo. Mesmo com os apelos de Gomes Freire para que permanecessem, os mesmos desertores diziam que:

"se não fiavam pois eu os queria enganar para os entregar, e que antes iriam morrer entre as Feras, que convir em passar a outra banda do Uruguai; e o que mais me admira é a brevidade com que a outra banda do Rio passou um tal número de pequenos, dois destes, e dois adultos dizem se afogaram"44.

O Governador de Buenos Aires, ao saber das notícias, demonstrou surpresa e ponderou que tais atitudes dos índios eram fruto das histórias infundidas pelos paulistas no imaginário dos mesmos. A ação, qualificada por Gomes Freire como loucura, era justificada pelo ódio dos indígenas aos espanhóis e o medo de uma possível escravização nas Missões. Sobre a possibilidade de abrir fogo contra os índios que, diante de necessidades, precisassem voltar ao forte português, Cevallos salienta que:

"seria muy conveniente al fin de remover este estorbo del objeto pr[incip]al, y al de que estos Vasallos del Rey no se extravien, q.e V.E. les hiciese algun mal tratamento conforme a la naturaleza de ellos para que volviesen como por asilo a nosotros, sin que para esto se considere necessário usar de las Armas" ${ }^{45}$.

A estratégia do Governador era clara. Para reaver os índios desertores, era necessário que os portugueses lhes conferissem algum mal para que, dentro do princípio de asilo político, os mesmos regressassem por conta própria a seus Povos de origem. Sendo estes bem tratados pelos espanhóis, não haveria motivações para outras fugas e, por estes meios, eram o bastante para conter futuras fugas indígenas, as quais não pareciam ter fim ${ }^{46}$. Ou seja, a política de bom tratamento destinada aos índios era objeto das duas Coroas numa clara disputa por súditos e vassalos dos governos ibéricos.

Em anos posteriores, a questão figurava de forma semelhante. Com a assinatura do Tratado de El Pardo, Cevallos possuía um argumento importante para garantir o retorno dos índios a seus povos de origem. Por isso, ele enviou o padre Diogo de Obregosa ao Rio Pardo; local para onde muitos índios foram levados. Contudo, os missioneiros afirmavam que não fariam a travessia de volta sob hipótese alguma e solicitaram que Gomes Freire

"os deixassem ir antes de ver o padre, e que para os mandar presos, escolhiam os mandasse degolar antes, que tornar donde alguns já haviam voltado açoitados e faltos de assistência" ${ }^{47}$.

\footnotetext{
${ }^{44}$ AGN. Sala IX. 28-2-21. Carta de Gomes Freire de Andrada a D. Pedro de Cevallos. Forte de J.M.J. 14/12/1757. Archivo General de Indias. Sessão V. f. 1.

${ }^{45}$ AGN. Sala IX. 28-2-21. Carta de Pedro Cevallos a Gomes Freire de Andrada. São Borja, 28/12/1757. Archivo General de Indias. Sessão V. f. 4. Grifos nossos.

${ }^{46}$ Idem. f. 5.

${ }^{47}$ Garcia, 2007: 57.
} 
Ao retomar o tema da deserção dos índios, o conde de Bobadela respondeu a Pedro Cevallos que todas as tentativas foram realizadas a fim de que a devolução dos mesmos fosse concedida. Por conseguinte, os índios reafirmavam seu interesse em não retornar aos domínios do Rei Católico. Nesse sentido, Cevallos acusava os portugueses de impedirem o retorno dos índios às Missões, acusação esta negada pelo Conde de Bobadela na medida em que o mesmo não considerava:

“aos Índios escravos, para que por este título me seja injusto conservá-los em os domínios de S.M., e deva fazer deles a restituição que V.E. pretende. Eles foram criados por Deus, livres por sua natureza como os demais homens tendo por isso esta liberdade a seu favor e presunção do direito positivo, fundado no natural, e Divino; e não podendo alguém obter contra a presunção de todos aqueles dois direitos sem pleníssima prova" ${ }^{48}$.

Além de obedecer as diretrizes estabelecidas pela Lei de Liberdades (1755) e o Diretório dos índios (1758), as autoridades portuguesas se utilizaram do tema da liberdade indígena para obter um maior número de súditos para sua Coroa. Num contexto onde se buscava minar a categoria jurídica do índio, assemelhá-lo ao escravo africano era uma estratégia pouco produtiva aos interesses ibéricos no conjunto de suas fronteiras. Produzir diferenciações entre índios e negros era, desta feita, fundamental para manter os indígenas sob domínio de um ou outro soberano. Portanto, "basta que os Indios declarem, que são livres, para ninguém obter que eles se julguem por escravos sem mostrar a sua escravidão por modo concludente e superior a toda controvérsia" ${ }^{49}$.

Cevallos reclamava às autoridades portuguesas a devolução desses indivíduos. Contudo, tal princípio não era atendido sob a alegação de que estes índios foram alijados do restante da sociedade colonial hispânica ${ }^{50}$ e que o gozo de liberdade nas terras portuguesas os livraria da escravidão injusta a qual viviam. Novamente, vemos a dicotomia liberdade versus escravidão inserida no discurso lusitano como um argumento em favor dos índios migrados às terras do Rio Grande.

Em continuidade a este argumento, uma instrução enviada ao Conde da Cunha em 1765 esclarecia que os índios Tape e Minuanos que se achavam com os portugueses em Viamão deveriam ser empregados para "desabusar os seus Nacionais" dos enganos com os quais os jesuítas os conservavam na escravidão. Na América lusa, os índios eram livres e donos de terra ${ }^{51}$. Mas, Pedro de Cevallos estava disposto a agir com severidade na questão, insistindo pela restituição destes índios para

" $1^{\circ}$ evitar o perigo de se habituarem conosco para irem desabusar os seus Nacionais; $2^{\circ}$ Extinguir os tais Índios com tiranias, que encham os outros de horror, para não vir buscá-los. $3^{\circ}$ Persuadir os outros Índios das suas Aldeias, que lhes sucederá o mesmo se vierem para as Nossas Terras, porque nós somos

\footnotetext{
48 AGN. Sala IX. 28-2-21. Carta do Conde de Bobadela para D. Pedro de Cevallos. Rio de Janeiro, 29/01/1762. Archivo General de Indias. Sessão V. f. 11.

${ }^{49}$ Idem.

50 IHGB. Cartado Sr. Conde de Azambuja - vice - rei e capitão geral do Estado do Brasil. Capela de Viamão, 10 de janeiro de 1768 (Revista Trimestral..., 1868: 281).

51 ANRJ. CÓPIA para o Conde da Cunha em resposta da Representação do Coronel Francisco Pinto do Rego e mais Pessoas principais da Capitania de São Paulo, que veio resposta na sua carta de 29 de fevereiro de 1764. Palácio de Nossa Senhora da Ajuda, 26/01/1765. f. 81. Cód 67, vol. 3.
} 
Gentes tão cruéis e tão aleivosas que entregamos com perfídia negra ao sacrifício os mesmos Índios que vieram buscar-nos para viver conosco" ${ }^{25}$.

Além disso, havia um interesse implícito de manter os índios em locais como Viamão e no Rio Pardo, expressa nas recusas de Gomes Freire em atender os apelos do Governador de Buenos Aires ${ }^{53}$. Em 1763, no contexto da tomada da região do Rio Grande pelos espanhóis, José Custódio de Sá e Faria dava suas impressões do evento e sinalizava ao Conde de Bobadela, responsável pelas partidas demarcadoras, a chegada de novas famílias índias a fronteira do Rio Pardo, acompanhadas pelas tropas portuguesas:

"Experimentando os índios a docilidade com que os tratamos enquanto durou aquele quartel, e mais que tudo por se aproveitarem da ocasião, que a fortuna lhes oferecia, de saírem da escravidão em que se achavam ao tempo que marchávamos dos ditos povos para o rio Pardo, nos acompanhou um grande número de famílias; e advertindo o $\mathrm{Illm}^{\circ}$ e $\mathrm{Exm}^{\circ} \mathrm{Sr}$. conde de Bobadela que o general espanhol lhe poderia fazer alguma carga, incubando que ele lhe desinquietava os índios para os trazer para o nosso domínio (...) pela outra parte a tropa lhe dava todo o auxílio de passarem seguros, por compreender que nosso general assim o queria" ${ }^{54}$.

Após a tomada do Rio Grande, Cevallos procurou novamente reaver os ditos índios. Gomes Freire, à época falecido, foi substituído pelo Conde da Cunha no governo do Estado do Brasil, que era um homem favorável a devolução dos guarani aos espanhóis sob a alegação de que, no Brasil, havia muitos índios. Porém, a Corte portuguesa não aceitou com bons olhos esta ideia e reiterou a intenção de manter os índios junto aos colonos. Na perspectiva do Marquês de Pombal, a percepção de um tratamento diferenciado aos indígenas faria com que eles percebessem a "escravidão" a qual estavam submetidos enquanto viveram com os espanhóis e, nesse sentido, a expulsão dos jesuítas na América hispânica ganha um novo entendimento na medida em que estes representavam uma ameaça ao retorno dos nativos aos povos de origem ${ }^{55}$. Contudo, como Francisco Xavier de Mendonça Furtado sinalizava em relação a Amazônia, era importante se precaver com os índios pois, da mesma forma que se rebelaram contra o rei católico, eles poderiam em algum momento se rebelar contra os portugueses ${ }^{56}$. Eram homens com lealdades divididas, potencialmente dispostos a trair aos soberanos que viessem porventura a obedecer diante dos benefícios que poderiam usufruir de um lado ou de outro da fronteira.

\section{Conclusões}

Com o insucesso do Tratado de Madri, a assinatura do Tratado de El Pardo sinaliza um outro problema no conjunto das fronteiras entre portugueses e espanhóis na

\footnotetext{
${ }^{52}$ Idem. f. 81-81v.

53 Garcia, 2007.

${ }^{54}$ Carta do Sr. Conde de Azambuja - vice - rei e capitão geral do Estado do Brasil. Capela de Viamão, 10 de janeiro de 1768 (Revista Trimestral... 1868: 282.

55 Garcia, 2007: 59.

56 Biblioteca Nacional. Carta de Francisco Xavier de Mendonça Furtado ao Marquês de Pombal. 18/03/1767. Divisão de Manuscritos. Biblioteca Nacional.
} 
América. De um lado, a necessidade de manter uma determinada territorialidade e, de outro, elaborar políticas de atração dos povos que viviam nessas paragens indefinidas. $\mathrm{O}$ conjunto das reformas pombalinas, no lado português, e bourbônicas, no lado espanhol, prezavam pelo fortalecimento do Estado e a centralização administrativa colonial. Por esse viés, as autoridades ibéricas precisavam manter uma estrutura política e administrativa condizente com as mudanças ocorridas na metrópole.

Contudo, podemos observar pelas linhas acima que ambos os Estados possuíam fragilidades dentro daquela estrutura forte que almejavam alcançar. Uma delas recaia justamente no controle das pessoas, em especial os povos indígenas e os negros escravos de ambos os lados da fronteira. No que diz respeito a este artigo, tratamos da questão da devolução de índios, a qual deveria ocorrer após a assinatura do Tratado de 1761, que punha fim a liberdade de permanecer ou não nos povos das sete Missões orientais do Uruguai. Os boatos envolvendo a escravização de índios guarani pelos padres da Companhia de Jesus eram acionados em momentos onde a transmigração e, consequentemente, o não retorno dos índios aos aldeamentos era colocado em questão pelos espanhóis. A liberdade em oposição a escravidão vivida nos territórios missioneiros abriu outras possibilidades aos indígenas e isto tornou-se parte de um conflito diplomático entre portugueses e espanhóis no Prata onde se promoveu uma verdadeira atração de súditos para ocupar os vastos territórios fronteiriços. Não obstante, a produção de diferenciações entre indígenas e africanos conduziu a produção de outras hierarquias dentro da sociedade colonial ibérica.

Portanto, as interações numa fronteira em disputa dificultava as ações de um Estado que pretendia ser forte. O controle do trânsito das pessoas era fundamental ao estabelecimento de uma ordem no rio da Prata colonial. As desigualdades em relação ao estatuto de livre dos indígenas persistiram na sociedade colonial; expressas através de situações como as fugas e a manutenção do contato que estes com os grupos infiéis ao longo dos anos. Homens divididos, os índios quando incorporados a sociedade colonial eram alvo de constantes desconfianças; mas também podemos assinalar as possibilidades que existiram para eles naquele contexto, servindo como uma "muralha de gente" a atender os interesses de Portugal ou de Espanha e tendo, em troca, alguns benefícios de um e de outro lado da fronteira.

Tal contexto produziu, desta forma, pessoas que mudavam de condição e de qualidade dependendo do lugar onde estivesse. Nesse ínterim, para além de uma disputa territorial, temos conformada uma disputa por súditos que ocorreu em outros espaços coloniais espanhóis ${ }^{57}$. Desta forma, as políticas destinadas aos índios promovidas pelos Bourbon tiveram de lidar, no espaço geográfico mais amplo do vasto Império espanhol, com esforços políticos semelhantes por parte de franceses, ingleses e portugueses que almejavam os mesmos súditos. Pode se concluir então que a orientação que se vislumbrava na aplicação das reformas Bourbônicas ao conjunto dos índios na América foi semelhante, mas obteve resultados variados conforme as ações das monarquias envolvidas e a importância geopolítica de cada territorialidade do Império ${ }^{58}$.

Assim, a elaboração de tratados e as consequentes flutuações territoriais ocorridas a partir de meados do século XVIII permitiu a manutenção de certas estratégias de sobrevivência e mesmo a recriação de outras formas de convivência

\footnotetext{
${ }^{57}$ Weber, 2000.

${ }^{58}$ Boccara, 2007: 56-72. Wilde, 2003: 105-135.
} 
social, nas quais é possível construir uma relação entre o território e as gentes que ali o ocupavam. Estar sob a tutela de Sua Majestade Fidelíssima representava, naqueles anos, possibilidades de liberdade em oposição ao escravismo e a exploração espanhola encabeçada pelos jesuítas; o que também contribuiu para a expulsão dos inacianos na medida em que os mesmos eram acusados de escravizar os índios e serem, dentro do discurso político produzido na época, o principal motivador da resistência indígena ao retorno aos povos do Uruguai. Por isso, pensamos de que forma as áreas fronteiriças abriram um leque de possibilidades e expectativas aos seus diversos agentes, atendendo a interesses medidos pelas circunstâncias do momento vivido tanto para a construção de um determinado território e, por conseguinte, da soberania, quanto por reunir em torno desses espaços aspirações individuais que poderiam vir a ser modificadas no simples traçado de uma linha divisória.

\section{Referências bibliográficas:}

Adelman, Jeremy (2006), Sovereignty and Revolution on the Iberian Atlantic. Princeton Unversity Press.

Almeida, Maria Regina Celestino (2001), Metamorfoses indígenas: identidade e cultura nas aldeias coloniais do Rio de Janeiro. Rio de Janeiro: Arquivo Nacional.

Barcelos, Artur H. F. (2010), “A cartografia indígena no Rio da Prata colonial”, $X$ Encontro Estadual de História. O Brasil no Sul: cruzando fronteiras entre o regional e o nacional. Santa Maria.

Boccara, Guillaume (2007), "Poder colonial e etnicidade no Chile: territorialização e reestruturação entre os Mapuche da época colonial”. Tempo. Niterói, nº 23.

Bolton, Herbert E. (1991), "La mision como institucion de la frontera em el septentrion de Nueva España”. Francisco de Solano e Salvador Bernabeu (orgs): Estudios (Nuevos y Viejos) sobre la frontera. Madrid: Consejo Superior de Investigaciones Cientificas.

Bombardi, Fernanda Aires y Chamboleyron, Rafael (2011), "Descimentos privados de índios na Amazônia colonial (séculos XVII e XVIII)”. Varia História, Belo Horizonte, vol. 27, $\mathrm{n}^{\mathrm{o}}$ 46, jul/dez.

Cortesão, Jaime (2006). Alexandre de Gusmão e o Tratado de Madrid, tomo II. Brasília/São Paulo: Funag/Imprensa Oficial.

Costa, Maria de Fátima (2009), "Miguel Ciera: um demarcador de limites no interior sul-americano (1750 - 1760)”, Anais do Museu Paulista, vol 17, número 2, julho - dezembro.

Filho, Synesio Sampaio Goes (2000), Navegantes, bandeirantes, diplomatas. Um ensaio sobre a formação das fronteiras do Brasil. Rio de Janeiro: Martins Fontes/ Biblioteca do Exército Editora.

Garcia, Elisa F. (2007), As diversas formas de ser índio. Políticas indígenas e políticas indigenistas no extremo sul da América Portuguesa, Rio de Janeiro: Arquivo Nacional. 
(2011), “Identidades e Políticas Coloniais: guaranis, índios infiéis, portugueses e espanhóis no Rio da Prata, c.1750-1800”, Anos 90, Porto Alegre, v. 18, n. 34.

(2007), "De inimigos a aliados: como parte dos missioneiros repensou o seu passado de conflitos com os portugueses no contexto das tentativas de demarcação do Tratado de Madri”, Anais de História de Além, mar, núm. VIII.

Kantor, Iris. (2014), "Novas expressões da soberania portuguesa na América do Sul: impasses e repercussões do reformismo pombalino na segunda metade do século XVIII". In: João Fragoso e Maria de Fátima Gouvêa (orgs). O Brasil Colonial, vol. 3. Rio de Janeiro: Civilização Brasileira.

Landers, Jane (1999), Black society in Spanish Florida. Urbana and Chicago: University of Illinois Press.

Maxwell, Kenneth (1997), Marquês do Pombal. Paradoxo do Iluminismo. São Paulo: Paz e Terra.

Monteiro, John (1994), Negros da terra. Índios e bandeirantes nas origens de São Paulo. São Paulo: Companhia das Letras.

Novais, Fernando (2011), Portugal e Brasil na crise do Antigo Sistema Colonial (17771808), São Paulo: Hucitec. $9^{a}$ edição.

Quarleri, Lia (2009), Rebelión y guerra en las fronteras del Plata. Guaraníes, jesuitas e imperios coloniales, Buenos Aires: Fondo de Cultura Económica.

Revista Trimestral do Instituto Histórico e Etnográfico do Brasil (1868), Tomo XXXI. Parte primeira. Rio de Janeiro, t.31, pt.1. Documentos sobre o Rio Grande de São Pedro, Santa Catarina e Colônia do Sacramento (extraídas do Arquivo Público).

Ribeiro, Mônica da S. (2014), "Razão de Estado" e pombalismo. Os modos de governar na administração de Gomes Freire de Andrada". In: Falcon, Francisco y Rodrigues, Cláudia (org). A "época pombalina" no mundo luso-brasileiro. Rio de Janeiro: FGV Editora/ Faperj.

Sampaio, Patrícia (2001), Espelhos partidos. Etnia, legislação e desigualdade na colônia. Manaus: Editora da Universidade Federal do Amazonas, 2001.

Weber, David (2000), La frontera española en América del Norte. México: Fondo de Cultura Económica.

Wilde, Guillermo (2003), “Orden y ambiguedad em la formación territorial del Rio de la Plata a fines del siglo XVIII”. Horizontes antropológicos. Porto Alegre. ano 9, n. 19. 